\title{
ORGANIC FARMING: AN ECOFRIENDLY WAY TO SUSTAINABLE AGRICULTURE
}

\author{
Daya N. Mandal, MSc. Pl.Gen.Resources. ${ }^{19}$
}

\begin{abstract}
Organic farm products have got more value as compared to inorganic products. People are becoming more conscious for their health and environment. Bio-farming is sustainable and eco-friendly which enables to conserve biodiversity and to protect environment. Organic farming system avoids or largely excludes the use of synthetically compounded fertilizers, pesticides, growth regulators, and livestock feed additives. It mainly relies upon crop rotation, organic manures, bio-pesticides and integrated pest management (IPM). In this paper emphasis has been given to practice in favors of organic farming, biopesticides, and preparation and use of organic manures by different methods in a hygienic manner.
\end{abstract}

\section{Introduction}

Organic farming is defined as production system, which avoids or largely excludes the use of synthetically compounded fertilizers, pesticides, growth regulators, and livestock feed additives. To the maximum extent feasible, organic farming systems rely upon crop rotations, crop residues, animal manures, legumes, green manures, off-farm organic wastes, mechanical cultivation mineral-bearing rocks, and aspects of biological pest control to maintain soil productivity and to supply plant nutrients, and to control insects, weeds and other pests (USDA).

Organic farming is a production system which favors maximum use of organic material (crop residues, animal excreta, legumes, on and off farm organic wastes, growth regulators, biopesticides etc.) and discourages use of synthetically produced agro-inputs, for maintaining soil productivity and fertility and pest management under conditions of sustainable natural resources and healthy environment.

\section{The Practices Organic Farming Favors are:}

1. Tillage that minimizes soil erosion even if it is more expensive,

2. Reliance on animal manures and green manures with minimal input of inorganic fertilizers,

3. Integrated pest management for pest control,

4. Management systems, such as crop rotations, that helps control weeds and disease organisms.

\section{Vermi-compost}

It is a method of making compost with the use of earthworms, which generally live in soil, eat bio-mass and excrete it in digested form. This compost is generally called vermi-compost. It is estimated that 1899 worms which is an ideal population for one sq. meter can feed on 80 tonnes of humus per year. To prepare an ideal vermi-compost, the following procedure is adopted.

\footnotetext{
${ }^{19}$ Senior Scientist (S-4), Napal Agriculture Research Council, Khumaltar. Email: dnmandalnp@hotmail.com
} 
Each shed measuring $20 \mathrm{ft} \times 80 \mathrm{ft}$ is to be constructed with the help of locally available material like bamboos, stems of trees etc. A hut type structure is built with the help of these articles. The roof is made from dried grass, typha leaves, bamboo sticks, etc., in such a way that the hut may be protected from rain water and sun heat. Each hut may accommodate at least four vermin-beds of $3 \mathrm{ft}$. width.

These beds are prepared by putting 2 to $3 \mathrm{~cm}$ thick layer of farm manure as first layer followed by 10 to $15 \mathrm{~cm}$ of bio-mass with 200-250 worms per sq ft. collected locally may be added and the bed should be kept sufficiently moist. This layer should be followed by a layer of 10 to $15 \mathrm{~cm}$ of half digested cow-dung layer which should be covered by a layer of leaves, trash etc., and water is sprinkled on the entire bed. The bed may be covered with palm leaves or coconut leaves or with any indigenous material. The pits should be kept constantly moist but never flooded.

A month later, the covered leaves should be removed and layers of organic waste not exceeding $6-7 \mathrm{~cm}$ should be added every alternate day. Watering should continue with each filling. When the pit is nearly full to a height of one metre, the material should be turned down to provide aeration. After a month, the heap will be ready for harvest with good quality vermi-compost. The dug out vermi-compost should be heaped in an open place. The worms will find way to the bottom of the heap. The vermi-compost from the top can be removed, dried and sieved for application in the field. The compost can also be enriched with micronutrients bacteria etc. by adding them externally, 16 tonnes of compost can be contained from 4 beds in 30 days after four months gestation.

\section{Bio-pesticides for Insect Pest and Disease Management}

Bio-pesticides are natural plant products that belong to the so-called secondary metabolites, which include alkaloid, terpenoids phenolics and minor secondary chemicals. Every plant species has developed in built unique chemical complex structure that protects it from pests. The plant kingdom offers us a diverse array of complex chemical structure and almost every imaginable biological activity.

\section{Insect Pest Management}

Most of the synthetic organic insecticides having high toxicity to pest species are often even more toxic to the beneficial insects like spiders, ladybird beetle and earthworms. Pesticides residue above tolerance limits have been reported in food, milk and even in human milk (Dhahiwal and Singh 1993). In view of these facts, the selection of insecticides for use must take account their toxicity to animals, human beings and useful organism, their persistence in air, water, soil and overall environmental impact of their use on agricultural crops (Dhahiwal and Arora, 1993). It is in this context that biological pesticides are being considered as environmentally safe, selective, biodegradable, economical and renewable alternative for use in organic farming system.

\section{Integrated Pest Management}

1. Cultural method

a. Clean cultivation; provides less chances to breed and survive the insects

b. Crop rotation and plowing; potato tuber moth's population is reduced if crop is not grown there for few years. Sugarcane borer, whiteflies, and black bug are greater on ratoon crop than newly planted crop

c. Variation in time of planting eg. Early planted rice is saved from rice borer 

d. Proper use of fertilizers and irrigation
e. Use of resistant varieties
f. Trap crop and intercrop
g. Pruning

2. Mechanical and physical control: Hand picking of larger size insects eg. Eggs and larvae of cabbage butterflies and larvae of mustard saw fly.
a. Legal control
b. Biological control; Parasites and predators. Wooly aphids are controlled by a parasite Apanteles glomeratus. Similarly ladybird beetle, syrphids, chrysopa, Nabis, Mantids can prey on number of insects

3. Biopesticides
a. Fungi- Beauveria, Entomophthora
b. Bacteria- Bacillus thuringiensis
c. Virus- Nuclear polyhedrosis Virus (NPV)

4. Use of pheromones and hormones; Potato tuber moth

5. Use of attractants, repellants and sterilants

6. Botanical pesticides; Margosom a neem product @ $1.5 \mathrm{ml} /$ liter against aphids, whiteflies, jassids, mites and scale insects

7. Traditional method; Dry wood ash applied during early morning hours gave better protection than other time of day. Wood ash soaked in ether for a period of over night and sieved through fine cloth and mixed with soap water then spray on vegetable crops gives good protection against aphids and soft bodied insects

\section{Compost Making}

It is the biochemical degradation of organic material to yield a sanitary soil supplement. It is the only process, which provides for recycling of organic matter (residues). The process can handle garbage and other organic refuse (but not plastic) as well as sewage sludge and waste from certain industrial operations such as saw and paper mills. The biodegradable wastes such as animal and vegetable wastes, lawn cutting, garden trimming, leaves etc. should be used for preparing compost by adding to it synthetic nitrogen, phosphorous and potash fertilizers. Compost fertilizers can be latter used for agricultural purpose. The main plant nutrient viz, nitrogen, phosphorous, potash are contained in the compost. The quantity varies widely depending upon the nature of materials being composed.

\section{Methods of Compost Preparation}

- $\quad$ Pit method

- Heap method

Pit size: $5 \mathrm{~m} \times 2 \mathrm{~m} \times 1 \mathrm{~m}$ pit can contain about 10 ton prepared compost. The length and width of the pit can be varied according to our convenience but depth should be either $1 \mathrm{~m}$ or less if water logging is a problem. After every layer, inoculums, complexal, lime and water should be sprayed over the composting material. Besides, prepared compost, poultry manure and ash can also be used as inoculums.

\section{Other Methods of Organic Manures are}

1. Green manure in-situ 
2. Green leaf manure ex-situ

3. Concentrates organic manures; cakes, meat meal, bone meal

4. Bio fertilizers; Rhizobium, Azotobactor, Blue green algae, Azolla , Mycorrhizae etc

Organic Farming in Kitchen Garden, glass house and other fields

- Use organic manures

- Regular monitoring the garden for insects and diseased plant population.

- Use organic manure instead of inorganic fertilizers

- Use organic pesticides

- Mushroom cultivation

- Flower cultivation (floriculture)

\section{Conclusion}

To sum up, organic farming is an eco-friendly approach to sustainable agriculture whereas application of synthetically compounded fertilizers, growth regulators, livestock feed additives and pesticides cause environmental and health hazards. The use of pesticides, especially on vegetable crops such as brinjal and tomato has carcinogenic effect on human health. The IPM is one of the best ecological approaches that minimize the cost of farming by using bio-fertilizers and pesticides and at the same time it increases quality of the products. It plays a tool for safeguarding environment by conserving agro biodiversity in farmer's field.

\section{REFERENCES}

1. Dahama A.K., 1997: Organic Farming for Sustainable Agriculture, Bikaner 334003, India: Agrobotanica,

2. Dhaliwal, G.S. and Arora, R 1993. Changing status of insect pests and their management strategies. In: K.S.Gill, G.S. Dhaliwal and B.S. Hansra (eds). Changing Scenario of Indian Agriculture. New Delhi: Commonwealth Publishers, pp 98-145

3. Dhaliwal, G.S. and Singh, B. (eds). 1993: Pesticides: Thesis Ecological impact in developing countries, New Delhi: Commonwealth Publishers.

4. IRRI, 1988: Green Manuring in Rice Farming, Proceedings of a symposium on Sustainable Agriculture. 